\title{
Work ethic and degrowth in a changing Atlantic Canada
}

\author{
Karen Foster $^{1}$ \\ Dalhousie University, Canada
}

\begin{abstract}
This article draws on interviews, observations, and surveys from two mixed-methods sociological studies of people's relationships to paid and unpaid work to argue that the concept of the work ethic is a fruitful entrypoint for exploring critical issues of work, leisure and consumption in rural places, and indeed anywhere there are efforts to realize degrowth strategies. Then, I survey some of the major themes about work in a selection of widely-cited degrowth writings and argue that the work ethic could use more attention-particularly the question of how the dominant work ethic at any place and time might constrain or enable degrowth as a political-ecological aspiration. This question is actually a hopeful one, because it suggests that in-depth studies of instances where something other than the Protestant, capitalist (i.e. expansion-oriented) work ethic dominates can (and already do!) show us the kinds of culturally-embedded relationships to work that are complimentary to a degrowth agenda. Moreover, such studies show that alternative modes of working are viable. In other words, sociological and anthropological studies can provide empirical evidence that vibrant, meaningful human life can continue in the absence of constant economic growth.
\end{abstract}

Keywords: Degrowth, employment, work, work ethic, sociology, anthropology, rural

\section{Résumé}

Cet article de revue s'appuie sur des entretiens, des observations et des sondages réalisés lors de deux études sociologiques sur les relations entre personnes à propos du travail rémunéré et non rémunéré, afin d'affirmer que le concept de l'éthique du travail est un point d'entrée fructueux pour explorer les questions essentielles sur le travail, les loisirs, et la consommation dans les zones rurales, et en effet, partout où il existe des efforts de mener des stratégies de décroissance. Celle-ci est une question optimiste, car elle suggère que ces études de cas approfondies où une autre chose que l'éthique protestante, capitaliste de travail (c.-à-d., axée sur l'expansion) peuvent (et le font déjà!) nous montrer les types de relations culturellement intégrées au travail qui sont complémentaires à un programme de décroissance. En outre, de telles études montrent que d'autres modes de travail sont viables.

Mots clés: Décroissance, emploi, travail, éthique du travail, sociologie, anthropologie, rural

\section{Resumen}

Este artículo se basa en entrevistas, observaciones y encuestas de dos métodos mixtos de estudios sociológicos de las relaciones de las personas con el trabajo remunerado y no remunerado para argumentar que el concepto de la ética del trabajo es un punto de entrada fructífero para explorar temas críticos de trabajo, En los lugares rurales, y en cualquier lugar hay esfuerzos para realizar estrategias de decrecimiento. Esta pregunta es realmente esperanzadora, porque sugiere que los estudios en profundidad de casos en los que algo más que la ética de trabajo protestante, capitalista (es decir, orientada a la expansión) puede (y ya lo hacen!) Mostrarnos los tipos de cultura incorporada Relaciones con el trabajo que son complementarias a una agenda de decrecimiento. Además, estos estudios demuestran que los modos alternativos de trabajo son viables.

Palabras clave: Decrecimiento, empleo, trabajo, ética del trabajo, sociología, antropología, rural

\footnotetext{
${ }^{1}$ Dr. Karen Foster, Canada Research Chair in Sustainable Rural Futures for Atlantic Canada, and Assistant Professor in the Department of Sociologv and Social Anthropology at Dalhousie University in Halifax, Nova Scotia, Canada. Email: karen.foster@dal.ca. Thankyou to Lisa Gezon and Susan Paulson for their thoughtful feedback and support for this article. This is the thirteenth article in Lisa L. Gezon and Susan Paulson (eds.) 2017. "Degrowth, culture and power", Special Section of the Journal of Political Ecology, 24: 425-666.
} 


\section{Introduction}

A man does not 'by nature' wish to earn more and more money, but simply to live as he is accustomed to live and to earn as much as is necessary for that purpose. Wherever modern capitalism has begun its work of increasing the productivity of human labor by increasing its intensity, it has encountered the immensely stubborn resistance of this leading trait of precapitalistic labor. And today it encounters it the more, the more backward (from a capitalistic point of view) the laboring forces are with which it has to deal.

Max Weber (2002[1904-1905]), The Protestant ethic and the spirit of capitalism, ch.2

Anyone who rejects the "growth paradigm" (Latouche 2014) must eventually consider how a postgrowth, slow-growth or no-growth society will or should transform how people and communities go about the task of "making a living" (Watson 2009). If we work toward, or are forced to adapt to, economies that do not continuously grow-that is, produce and consume more commodities-what will this do to waged work, social reproduction, care work and "autonomous" (Gorz 1999) provisioning? If we accept that a continuation of the current growth-for-growth's-sake model is undesirable or impossible, these are inevitable questions.

Accordingly, some visions of degrowth societies or economies contemplate a redistribution of work time, so that people (on average) are "working less" in paid jobs and, relatedly, "consuming less" (Latouche 2010: 9). For example, Serge Latouche writes that "shortening the working week is [...] an essential element" of any degrowth plan (2010: 40); for Samuel Alexander, "work reduction is one of the defining characteristics of a desirable macroeconomics beyond growth" (2012: 360). Jeroen Van den Bergh counts "work-time degrowth" as one of the "five main interpretations of degrowth" (2011: 3), and appreciates work-time degrowth because it is "a very concrete, one-dimensional aim and [work's] reduction is easily interpretable" (p.3).

As a sociologist interested in work and degrowth, I find myself contemplating the varying implications that work-time reductions have for social imaginaries. How we envision work changing matters, not only for how degrowth is understood as a concept or a school of thought, but also for how degrowth might be studied as an empirical phenomenon, analyzed as a "utopian demand" (Weeks 2011), or pursued as a political goal? My contribution is to ask how ordinary working people's orientations toward and relationships to work-not just as a source of spending money and an engine for consumption, but also as a social institution and a source of identity, purpose and social affiliation-factor into the growth society and its alternatives (Foster 2013).

In this article, I introduce the concept of the work ethic developed by Kathi Weeks (2011) and Max Weber (2002). I then describe the findings from my own research that have brought me to think about the work ethic in relation to the growth paradigm. Then, I survey some of the major themes about work in a selection of widely-cited degrowth writings, looking for whether and how the work ethic features therein. I conclude that examinations of the work ethic across time and place, using ethnographic tools such as case studies, interviews (including surveys) and participant observation, can offer a wealth of critical information for anyone studying or working to bring about a society that does not presuppose economic growth. In-depth studies of places and times where something other than the Protestant, capitalist (i.e. expansion-oriented) work ethic dominates can (and already do!) show us the kinds of culturally-embedded relationships to work that are complimentary to a degrowth agenda, and at the same time show that they are viable. In other words, sociological and anthropological studies can provide empirical evidence that vibrant, meaningful human life can continue in the absence of constant economic growth.

\section{The work ethic as a source of hope}

Although one of sociology's canonical texts-Max Weber's The Protestant work ethic and the spirit of capitalism (2002[1904-1905]) — is entirely devoted to an examination of the work ethic, there is surprisingly little theoretical or empirical work in the contemporary discipline that engages with that central concept. Kathi Weeks's (2011) The problem with work is an important and recent exception.

Weeks and Weber both tackle the question of how beliefs and values about work-why we do it, how much we should do, how we should feel about it, and what we should receive in return-change over time. Weber's focus was on the shift from the "traditional work ethic," dominant in the pre-industrial era, to the 
"protestant work ethic" that accompanied and, according to Weber, hastened capitalist industrial development. In the traditional work ethic, work was seen as "necessary drudgery" "to be avoided as soon as customary and constant economic needs were met" (Weber 2002[1904-1905]). People's motivation to work was simply to be able to live as they were accustomed. In contrast, in the protestant work ethic that came to nearly replace the traditional work ethic in an industrializing America, work was elevated above "the 'worldly' realm of pragmatic considerations [and,] to the devout, endowed with subjective meaning" (ibid.). Work, according to this new ethic, was not something to be sought in times of scarcity and abandoned in times of plenty. Rather, it was a vocation, a calling, a marker of status, and the meaning of life itself. As the protestant work ethic began to detach itself from actual protestant religious beliefs, it also began to posit work as something one should do not because it is a calling, but as if it is a calling. For Weeks, a similar small shift is taking place today; "Just as the Protestant ethic encouraged workers to treat their work as if it were a calling, today one noteworthy management technique involves asking workers to approach their work as if it were a career" (2011: 72, emphasis added).

But beyond this subtle replacement of the phantom of the calling with that of the career, according to Weeks the protestant work ethic's assumptions - that hard work and long hours are both virtuous and inevitable - endure, particularly in North America, but across advanced capitalist countries. This is important because it is these countries that usually set the tone for (or more directly control of) international economic and social policy. One reason for the protestant work ethic's persistence is that it has been reified, such that "at present one must work to 'earn a living"', and as a result this "is taken as part of the natural order rather than as a social convention" (Weeks 2011: 3, emphasis added). Thus, we work because we have to and because we want to. But Weeks points out that while both of these "explanations are undoubtedly important, they are also insufficient;" it is not just "structural coercion" or "individual consent" that pushes work to the center of life (37). There is also "the official morality—-that complex of shifting claims, ideals and values—known as the work ethic" (38).

Yet, my own research in the sociology of work and rural sociology, like Weeks' (2011: 80-81), suggests that the protestant work ethic does not play out evenly and without significant opposition across contemporary societies. In the research for my dissertation-and 2013 book, Generation, discourse and social change- I interviewed a diverse sample of 52 people, mostly from urban areas of Ontario and Nova Scotia, Canada, from a range of occupations, life stages and socioeconomic and cultural backgrounds, about work: why they do it, how they feel about it, and how they make sense of changes in the world of work since they started working. It revealed something intriguing about the work ethic and what Weeks calls the "work society," where work is "not only the primary mechanism by which income is distributed, it is also the basic means by which status is allocated, and by which most people gain access to healthcare and retirement" (2011: 7). While a good proportion of the people I interviewed were adamant about the importance of "being productive," no matter the social value of the productivity, the other proportion were very critical of work-for-work's sake and growthfor-growth's sake. The people in the latter camp had been unable to find employment that was well-paid and meaningful, so all of them had decided to prioritize meaning over pay, and included "time for leisure" among the things that made work meaningful. The following quotation from one interviewee, Bettina (31, freelance journalist), illustrates this relationship to work:

It's not that I'm lazy but I just don't—I don't wanna wake up doing something I really don't wanna do just so that 40 years down the line I'll have enough money to do whatever I want or even, like, buy a house cause that's ... that is not my goal at all and I think that's what my parents' goals are to like, to buy a property and make sure you have cars and stuff like that and I have a minimalist approach to what makes me happy in life I guess so ... that is not as necessary.

Jake, a 41-year-old visual artist, had a similar perspective:

I do say to some friends, you know, 'it's not worth it' and [they say] 'well, you know, five more years I get my pension.' ...It's like 'five more years? What happens if in six years you die?' ...When you go travel you'll see the retirees going....with a walker...they may have the money but they can't really enjoy, you know... 
Some participants who shared these relationships to their work were able to do exactly the job they wanted to, while others went for something that wasn't their dream job, but didn't intrude too much on their lives outside work. Most people in these interviews believed in the need for balance between work and non-work, and would have traded more leisure time for a raise. In most cases, only structural circumstances-the culture of their workplaces, the unexpected job loss of a spouse, and/or the lack of options in their work arrangementsput them in the position of having to trade leisure for money (Foster 2013).

These findings prompted me to trace the history of productivism in a new book, and with it the history of work resistance (Foster 2016). And it has since seeped into my current research, still in the preliminary fieldwork stage, in rural Atlantic Canada. Many business owners and craftspeople in Nova Scotia and the other Atlantic Provinces work on a seasonal basis, running their shops and producing handicrafts in concert with the rhythms of the tourist season. Rather than looking for ways to increase exports and online sales in order to keep their operations running consistently through the winter, many choose to shut down and take a break from paid work from January to April. The work ethic that separates these people from those who have tapped into new markets, scaled up production and sought year-round viability is one subject for my ongoing research.

There are two telling anecdotes I can share at this early stage. The first is from a focus group conducted as part of a study of the potential for Import Replacement (Jacobs 1985) as a rural economic development strategy. Participants in the focus group explained that logging operations in their community were sustained "under the table" because employers wanted to avoid paying overheads on employees. Employees, most of them fishermen trying to supplement their incomes in the off-season, accepted this arrangement because it allowed them to avoid taxes and perhaps collect Employment Insurance (EI, a federal program, fully funded by employee and employer contributions made during the on-season). In fact, the focus group participants estimated that many people in their rural community made half their incomes in the so-called "informal economy." When the focus group facilitator, a member of the research team, summed up positively that this was the "upside" to "seasonality"— that people are "able to be diversified in their livelihoods"—a participant retorted: "They're forced to be." This exchange serves, I think, as a reminder that work ethics must be understood as embedded in societies that are structured by power relations. We cannot be overly romantic about how people piece together a livelihood on the rural periphery, nor can we interpret their decisions as entirely free. But nor are they entirely coerced or oppressive. Participants told us that earning and spending in the informal economy was "the most efficient way to spend money around here." It is at once a "survival strategy," they said, and an act of proud resistance to the outside interventions meant to pry them from the communities they call home. Work ethic(s) and the actions they inspire are, then, an expression of one of sociology's central dichotomies: that of structure and agency.

The second anecdote is from a small coastal community of about 160 people in Newfoundland and Labrador. In an initial consultation with a resident, scoping out possibilities for focus groups and interviews about local production and consumption there, the informant suggested that residents of his community needed someone to come in and help them take their provisioning strategies_canning, fishing, hunting and trapping, handicrafts — and "upscale them" to bring them to bigger markets. I asked if he thought people actually wanted to do that. He paused and then admitted they probably wouldn't, even if given all the help they needed to do it. They were satisfied with the quality of life in their small fishing community, where about ten people are technically employed year-round and the rest are small producers or unemployed homemakers.

Indeed, there are countless examples from ethnographic research in the sociological and anthropological traditions of societies, moments and movements where a different work ethic dominates. Richard Lee's fieldwork with the Kalahari San or "bushmen" revealed a culture in which the arduous work of agricultural practice (planting, tending, harvesting) was rejected in favour of subsisting (quite healthily) on the abundance of mongongo nuts that grew on their own and fell on the ground (Lee 1968: 33). The San did not, evidently, feel that their lives were "lacking" until they were confronted by European and American travelers with "needs" they had never considered having_clothing, for example. They did not work (gather food, hunt) more than two and a half days out of every seven, spending the rest of the time entertaining visitors, resting, dancing, or doing embroidery (p.37).

This "subsistence mentality" confounded colonizers everywhere who entered so-called "primitive" societies hoping to industrialize them (Donkin 2010). Henry Ford, in his quest to set up a rubber plantation and automotive factory in the Amazon - in the community he called Fordlandia-was frustrated by the fact that the locals he tried to employ were content to work for a few days, make a hundred dollars, and then go home and 
rest for weeks. They had no desire to earn more and more, just for the sake of it (Grandin 2010: 155). Schmink and Wood, in their seminal study of Amazonian indigenous societies (1987), called this orientation toward work "simple reproduction."

In The protestant work ethic, Weber describes "a village of weavers who all produce the same thing," but they are not, as conventional economics would have it, "competing fiercely with one another." Instead, they are "cooperating with one another in reproducing customary arrangements that enable each and all of them to procure means of livelihood without sacrificing their lives to work" (Krippner et al. 2004: 126). Instead of the economists' "'equilibrium'" based on "relentless competition of all against all," they achieve a "social equilibrium," and at its heart is the traditional work ethic (Ibid.). The social equilibrium is only "broken" when a merchant comes into the village and links "rural producers directly to urban wholesalers and consumers and thereby bypassing the weavers in the village" (Ibid.). As explained in the introduction to this Special Section, this kind of market expansion features in narratives of economic progress as "apolitical and impartial", but Weber's case study is one among countless windows onto the "colonization of human habits and worldviews by market-relations and money-value" described by Polanyi and others (Paulson 2017: 440).

There are parallels between these early capitalist encounters with the traditional work ethic and the contemporary schemes that seek to put people in Nova Scotia, Canada-which depends on seasonal industries, like fishing and tourism - to work all year round, when they appear content to combine seasonal work with under-the-table jobs in the off-season, or to collect Employment Insurance for the months in which they are unable to do their jobs. If one looks at a graph of EI claims since 1973, the uptake of EI in this region barely fluctuates, through recessions and booms, through substantial changes to EI eligibility, through changes in government and an onslaught of programs meant to incentivize and even partially subsidize industrial work.

And while this causes current governments and the rest of the country a great deal of consternation, for those of us who critique the endless pursuit of economic growth it represents the slim hope that perhaps not everyone is addicted to work; that perhaps the traditional work ethic, which prioritizes only comfortable subsistence, relative to one's immediate neighbours (Sahlins 1968) and not, for example, relative to Wall Street tycoons or even civil servants in the urban centres, is still alive and kicking in certain places. It supports as well the compelling findings of the Sustainable Livelihoods Approach (SLA), that rural households are more resilient and stable when they make a living from multiple, diverse, waged and unwaged provisioning activities than a single waged job (Gibson, Cahill and McKay 2015). Just as the adaptations and politico-moral commitments of communities featured in the other articles in this Special Section offer hope that degrowth mentalities are already shaping social life in workable ways-it is this traditional work ethic that represents what Kathi Weeks, borrowing from Foucault and Deleuze and Gauttari, calls a "line of flight" (p.81) away from productivist, growth-centric society and toward a sustainable vision (Berglund 2017; Cox Hall 2017; Devore 2017; Gezon 2017; Lockyer 2017). It is to such visions of degrowth, and what they say (or don't say) about the work ethic, that I now turn.

\section{Work and degrowth}

Any "critique of development" (Latouche 2010: 9), including resistance to growth for growth's sake, and the embrace of the stable or shrinking economy (Alexander 2012), automatically entails changes to the way people work to make a living and secure their survival. But degrowth thinkers take a number of different routes between the first step of asserting a critique of growth for growth's sake and the second step of imagining work transformed.

In some instances, work hours reductions are a proactive strategy for decreasing production and ushering in a steady-state or shrinking economy. Assadourian (2012), for example, writes that degrowth can be achieved through a range of measures, including "shortening work hours" (1). Van den Bergh, again, sees work hours reductions as an "effective strategy to reduce consumption and associated environmental pressure," one that is better "than directly trying to reduce the quantity of consumption" (2011: 3). For Alexander (2012), degrowth depends on "eliminat[ing] "the structural biases that function to promote overwork, such as laws that treat the 40-hour work week as 'standard' and which exclude part-time employees from many nonpecuniary benefits enjoyed by full-time employees" (Alexander 2012: 361). Shortening the work-week, in his view, "would privilege leisure over consumption and systematically distribute labour in a slowly contracting economy"" (Alexander 2012: 361). 
These visions dovetail with another: the notion that a steady or shrinking economy will lead us to, rather than result from, the reduction of work hours. In this understanding, work reductions are seen as a reactive policy, a way to curb the unemployment that will inevitably increase if we improve productivity while decreasing or holding outputs constant. On the one hand, this is a projection of a future situation we cannot know; on the other, it is a logical extension of prior experience. If in the 1930s, "consumerism emerged as the path out of depression" (Nørgård 2013: 62), what do we have as an antidote to productivity-induced unemployment other than ramped-up consumerism? The rationale is simple, and Alexander explains it well:

In a non-growing but qualitatively developing economy, technological advances would presumably still enhance the productivity of workers over time; but this could lead to increasing rates of unemployment, since less labour would be needed to produce the same (non-growing) economic output. This phenomenon, along with increases in population, are the main reasons why conventional macroeconomists insist that growth is essential; that is, it is needed to avoid unemployment spiraling out of control. In a macroeconomic framework not based on growth, however, a stable system could still be achieved, but through the alternate route of reducing the workweek and sharing work more equally amongst the population. (Alexander 2012: 360)

As a reactive policy, then, work hours reductions are forwarded as a means of redistributing remaining jobs after others have been made redundant by technological advancement (cf. Illich 1978: 14; Latouche 2010: 77) without resorting to increased production to put more people back to work.

Often, both of the above assumptions are held at the same time; work hours reductions are imagined as both cause and consequence of degrowth, as both proactive strategy to get there and reactive strategy to deal with the repercussions. Moreover, thinkers beginning with the long tradition that begins in the 1700s with economists interested in the steady-state economy (e.g. Lafargue 1907; Mill 1909; Russell 1935; cf. Foster 2016), take care to point out that steadily increasing labour productivity has historically been used to enable greater and greater consumption instead of enabling more leisure, signaling that they believe that we are already at a state where we could conceivably take advantage of our great productivity by reducing work. But many also go on to propose that we could further reduce work time in order to shrink output and consumption and reduce anthropogenic contributions to climate change. Thus, reducing the work-week or the work-day is seen, across degrowth writings, as a way of making up for the long undelivered promise of the leisure society that has been strived for in the past and creating the conditions for a stable or shrinking economy in the future.

Importantly, with few exceptions (e.g. Alcott 2013), the emphasis across these distinct but related visions of degrowth is on the reduction of "heteronomous work"—work that is "done at the behest of a boss," as Ivan Illich writes, under "the corporate control of a corporation, volunteer agency, or labour camp," in which "the work process is planned, monitored, and controlled by a professional agent, who insures that the work meets a certified need in a standardized fashion" (Illich 1978: 83-84). Although it is common for degrowth thinkers to assuage fears that economic stasis will mean a return to primitive life (Paulson 2014) and drudgery (Latouche 2010: 78), few are explicitly interested in reducing autonomous work-work that is done for pleasure, work that is defined as "the creation of value perceived by the worker" (Illich 1978: 83). Further below, I explore what degrowth's advocates believe the reduction of heteronomous work and the expansion of autonomous work means for "free time" in degrowth societies.

\section{Reducing work and reducing consumption}

In the literature reviewed here, reducing heteronomous work goes hand-in-hand with reducing commodity consumption. Their relationship is generally assumed to be cyclical, such that reducing work reduces "income and thus spending power which in turn limit[s] consumption" (van den Bergh 2011: 3), which reduces consumption's power as an incentive to work more, further reducing work - or at least reinforcing and normalizing the reductions that have taken place.

Another key argument is that our present level of consumption-in the high throughput, global Northis too high, that it qualifies as overconsumption. The latter is seen as cause and consequence of overwork (Assadourian 2012: 1). Alexander (2012), for example, focuses on overconsumption's function as a cause of overwork and growth, arguing that "if a politics of degrowth is ever to emerge it will almost certainly have to 
be driven from the grassroots up by a culture that embraces some notion of 'sufficiency' in consumption" (Alexander 2012: 362). But overwork has consequences other than overconsumption: it is also blamed for a variety of social ills and illnesses, including family strife, stress, time wasted and pollution caused by commuting, depression, isolation and a weak civil sphere (Assadourian 2012, Latouche 2009; van den Bergh 2011). In some visions, work-time reductions are pitched as "the carrot" to the "stick" of reducing consumption (Lorek and Fuchs 2013: 40)—-the benefit promised in return for the sacrifice of certain material luxuries and consumerism as a pastime.

Curiously, one can find in some literature references to the limits of work and consumption, and the proposition that we have surpassed both. Yet at the same time, one finds the seemingly contradictory assertion that the very problem with work and consumption in contemporary societies is that there is no end to overwork just as there is no end to growth and development, because there is no ceiling for consumption. In the pursuit of more and more consumable experiences and things - in the practice of what Veblen (1934) called "conspicuous consumption", all measures of "more," "less," and "enough" are relative (cf. Rojek 1995).

\section{Free time and degrowth}

Much writing is concerned with what people might or should do with their free time once work is reduced. The classic anxieties about the "leisure society"-that leisure would become increasingly "commercialized, and people would waste their time and money on pursuits that did nothing for the individual or common good" (Foster 2016; Veal 2009)_are avoided by the conditions set in a degrowth society through policies and income reductions, reducing consumption (Nørgård 2013: 64). With the possibility of an expanded realm of consumption eliminated, answers to the question 'what will people do with their free time?' are generally framed by two scenarios.

In the first scenario, people simply work less, usually because productivity-enhancing technology has been harnessed to free us from work rather than pay us more money. People who work less in this scenario are free to engage in civics, spend time with family, and cultivate hobbies and passions-all of the things that overwork and overconsumption presumably prevent them from doing to the fullest. As Latouche writes, they are afforded "the leisure to do one's duty as a citizen, the pleasure of the freedom to engage in freely chosen arts and crafts activities, the sensation of having found time to play, contemplate, meditate, enjoy conversations or quite simply to enjoy being alive" (Latouche 2010: 40-41).

In the other dominant scenario, the emphasis is not so much on people working fewer hours, period, as it is on them working differently: more time is actually spent in the second scenario on basic provisioning, producing things locally and at a small scale that would otherwise be imported from somewhere else. Less time is spent doing jobs in advertising or public relations; more time is spent doing bike repairs, growing vegetables, making and mending clothing. Ivan Illich's conception of convivial work (1978) fits this scenario-it is more work, in one sense, but it is autonomous, creative, and ostensibly liberating. In other words, autonomous work comes to dominate and replace much of the heteronomous work that currently squeezes everything else into tight little corners. Autonomous work—or work in what Nørgård (2013) calls "the amateur economy"—is done primarily to satisfy individual and community needs, in contrast to heteronomous work, which is mostly being done in order to generate profits that will grow the economy. People in Illich's vision of a degrowth or convivial society, in doing more autonomous and less heteronomous work, would thereby gain "the freedom to do things that are useful for oneself or one's neighbour" (Illich 1978: 83). Not everyone writing about degrowth picks up the exact distinction between autonomy and heteronomy, or between convivial work and other kinds of work, but many take a similar view. Assadourian, for example, imagines that shortening the work week and increasing job-sharing options would lead people to "increase the amount of self-provisioning they do" and engage in "informal economic opportunities like small-scale farming and community gardening, bartering, and repair," all of which are, for Assadourian, "new means for people to sustain themselves" (Assadourian 2012: 2).

Like most of the contrasting ideas explored thus far in this article, these two scenarios often exist sideby-side in the same piece of writing; one does not preclude the other. However, the writers examined here, and the published exchanges between them, seem to shift back and forth, depending on the point to be made, between emphasizing subjects whose free time expands as their work time contracts, and emphasizing subjects who find freedom and autonomy through new kinds of convivial work opened up or necessitated by the conditions of a degrowth society. 


\section{How to reduce work-hours}

Neither reductions in work-hours nor the more specific contraction of heteronomous work are assumed, in the literature surveyed here, to be reducible without some policy intervention. Most writers evince that the natural or reciprocal effects of decreased consumption will be insufficient to reduce work time on their own, and thus that there must be strong policy mechanisms to bring it about (Assadourian 2012). At the very least, most point to the need to do away with policies that promote or encourage-otherwise make rationaloverwork. In other words, a leap is not made directly to coercive measures. It may be enough to stop pushing for, or taking for granted, constant growth in work and commodity consumption, opening up a space in which it is not morally corrupt to work less, and nor is careful consumption a project of the fringe.

Alexander proposes introducing a suite of measures in this spirit, naming France's 35-hour week and Holland's 2000 Hours Adjustment Act, "which permits employees to reduce working hours to part-time simply by asking their employers" (Alexander 2012: 361) as model policies. For Alexander, such steps would have the cumulative effect of "privileg[ing] leisure over consumption and systematically distribut[ing] labour in a slowly contracting economy" (Alexander 2012: 361).

Although he does not get into as much concrete detail, Latouche lists work hours reductions as part of his "electoral programme for degrowth," implying that there would be some policy measure to induce reductions and introduce "job-sharing" (2010: 70). Van den Bergh, meanwhile, comes to the curious conclusion that the only way for governments to reduce work time is through a "moral suasion strategy," "warn[ing] against working too much" the way they do about smoking, eating junk food, and drinking alcohol (2011: 3). The only policy change he advocates is one that would "create a flexible labor market that allows for part-time work contracts," as if this alone would induce people to work less (p.8). Van den Bergh's assertion seems naïve in light of what others have pointed out, namely that employer norms combine with "social pressures" to ensure that "the labor market is not free and in most cases involves a choice between say 40 h per week or zero." This is what leads Nørgård to conclude that only "collective agreements on work time" can ensure that work is reduced evenly, equitably and sustainably (2013:65).

Relatedly, Martinez-Alier and his coauthors (2014) make the interesting proposition that some of the demands made by workers' unions, and in particular demands for work-time reductions, constitute a form of "working class environmentalism" and a source of hope for degrowth objectives. This suggests that policies to reduce work hours might come about through pressure from organized labor and, as Nørgård concludes, collective agreements. However, there is one major reason to be skeptical of this route: since 1930, due to rising consumerism, pressure from employers, and vacillating governments, North American workers' unions have more often, and increasingly, opted to translate productivity gains into higher incomes instead of shorter working hours (cf. Hunnicutt 1988, 1992; Nørgård 2013: 64).

Finally, one of the most popular measures to reduce work-time is the provision of a Basic Income (a.k.a. a "citizen's income" or a Guaranteed Annual Income) (Kallis 2011; Martinez-Alier et. al 2014: 43; Schneider et. al 2010). ${ }^{2}$ For many, a Basic Income is seen as a way to reduce the incentive to overwork (Alexander 2012: 361) because it can "detach the receipt of income from the production of value" (Livingston 2011). Like the work-hours reductions Basic Income is meant to induce, it is thought of both as a proactive strategy (reducing people's reliance on wage-work, removing the incentive to overwork) and a reactive strategy (reducing unemployment and mitigate income loss from work reductions).

\section{Whither the work ethic?}

In the literature reviewed here, there are sociological assumptions about the work ethic operating just beneath the surface. For example, there is a clear connection made between work and consumption, with the acknowledgement that consumption is endowed with a cultural or sociological significance that far exceeds its utility for satisfying basic needs. This matters to the work ethic because, as Weeks makes clear, the work ethic is also always an ethic of consumption-"one that avows the necessary, legitimate, and indeed ethical link between hard work and whatever might count in different economic phases as deserved and responsible spending" (Weeks 2011: 50). There are also oblique references to the work society. In some texts, work is presented as something we are obsessed with for cultural and sociological reasons, not just for our survival.

\footnotetext{
${ }^{2}$ See Van Trier (1995) for a history of the Basic Income demand.
} 
Latouche (2010), for example, points to our "addiction to 'the job', " asserting that we must be "weaned" from it, "as it is a major element in the tragedy of productivism" (p.40). But beyond these kinds of embedded assumptions about the sociological and cultural significance of work, I have found little in the way of theorizing, let alone studying empirically, how the work ethic contributes to the dominance of productivism and "the growth paradigm" (Ayres 1996; but cf. Slocum \& Gowan 2015).

Relevant work that I have found includes Nørgård (2013), who notes that public support for "restrictions on energy use"—such as would be required by degrowth—is limited at a most subconscious level by a "fear of free time" (p.61). People find it easier, he writes, to imagine "reduc[ing] wasteful physical consumption" than to acknowledge, let alone act on, the "environmental consequences of one's work" (p. 61). For him, the reason is none other than "the so-called Protestant work ethic," in which "hard work was to be considered a vocation or a calling, in the sense that it was good in itself, whether the output was needed or not" (p.64). Echoing Max Weber's seminal writing on the topic, Nørgård explains that the work ethic "was a blessing for the emerging industrialization", given that it could induce people to work beyond the point of satisfying their own basic needs. The sad irony is "that today this same work ethic is an essential element in the ecological threat the world is facing" (p.64).

In an article considering the compatibility between degrowth and a "Job Guarantee," Alcott (2013) acknowledges that the work ethic presents an obstacle to degrowth's desires. Accordingly, and "controversially," he argues that degrowth should pursue full employment through a Job Guarantee, effectively putting people to work through state-sponsored programs instead of reducing work time across the board. For Alcott, this is a pragmatic matter of "tak[ing] people the way they are, whatever sea changes in attitudes towards 'work' may be worth pursuing" (p.57). Justifying his position, he writes:

I believe we should start with the values and institutions of our given societies even if many in the degrowth movement find them pathological. Firstly, these are the voters we must convince, and secondly, the number of years remaining for a managed, humane transition to a smaller economy preclude waiting until deeper attitudes have been changed. In a world where 'the economy' is virtually synonymous with 'jobs', how can degrowth present itself as a job-killer? (2013: 57)

The "values and institutions" of which he writes are, in my interpretation, the work ethic's insistence on work as the only legitimate source of income, as a virtue, and as a good in itself. Alcott even falls into what Weeks would call "the valorisation of work"; casually accepting that "being involuntarily idle" causes as many problems as having no money (p.57). For him, it is both realistic and pragmatic, as a strategy to gain political support and as a means of making degrowth feasible in practice, to see "work radically as a social rather than an economic question" (p.58). Legislating full employment through a Job Guarantee would mean, in a roundabout way, decoupling degrowth's pursuit of environmental sustainability from the earnings and income security of individual workers, ostensibly weakening opposition to energy reduction and other degrowth policies. This would circumvent the false "economy versus environment" debate, because individual workers would not immediately see environmental regulations as a threat to their livelihoods.

\section{Studying the work ethic now}

The foregoing review suggests that there is a long and intriguing list of questions to be asked about the work ethic and paths toward a better world. Whether we wish to evaluate the impacts, observable or potential, of reducing work-time, curbing consumption or implementing a basic income, we could learn a lot by using the work ethic as a guideline for our research questions. We do not have to look far, wherever we are, for interesting sites where different work ethics entail different relationships to economic growth. The few examples I extracted earlier, from my own fieldwork, are not anomalous. There is evidence, for example, that the traditional work ethic survives and perhaps is being revived in rural areas where "neo-rurals" choose to abandon city life for a slower, more family- and community-oriented pace in the country (Cortes-Vazquez 2014: 505). These rural settlers emphasize that becoming or staying rural entails a struggle- that "you have to strive to do this," through occupational pluralism and self-provisioning, through "informal exchanges of gifts and favors between neighbors; baby, pet and house sitting; sharing food and leftovers and giving rides"—-but that these are not just struggles but also convivial acts, and that they are precisely the point of choosing to live 
outside the industrial production centres (ibid.). That this mentality exists should be a source of great hope for us. That it can be studied, documented and analyzed in the ethnographic tradition, should alert us to a greater role for anthropological and sociological research.

\section{References}

Alcott, B. 2013. Should degrowth embrace the job guarantee? Journal of Cleaner Production 38: 56-60.

Alexander, S. 2012. Planned economic contraction: the emerging case for degrowth. Environmental Politics 21(3): 349-368.

Assadourian, E. 2012. The path to degrowth in overdeveloped countries. In Starke, L. (ed.) State of the World 2012. Washington: Island Press. Pp. 22-37.

Ayres, R. 1996. Limits to the growth paradigm. Ecological Economics 19(2): 117-134.

Berglund, E. 2017. Steering clear of politics: local virtues in Helsinki's design activism. Journal of Political Ecology 24: 566-581.

Cortes-Vazquez, J. 2014. A natural life: neo-rurals and the power of everyday practices in protected areas. Journal of Political Ecology 21: 493-515.

Cox Hall, A. 2017. Neo-monastics in North Carolina, de-growth and a theology of enough. Journal of Political Ecology 24: 543-565.

DeVore, J. 2017. Trees and springs as social property: A perspective on degrowth and redistributive democracy from a Brazilian squatter community. Journal of Political Ecology 24: 644-666.

Donkin, R. 2010. The future of work. Palgrave Macmillan.

Foster, K. 2013. Generation, discourse, and social change. New York: Routledge.

Foster, K. 2016. Productivity and prosperity: a historical sociology of productivist thought. Toronto: University of Toronto Press.

Gezon, L.L. 2017. Beyond (anti)utilitarianism: khat and alternatives to growth in northern Madagascar. Journal of Political Ecology 24: 582-594.

Gibson, K., A. Cahill and D. McKay, 2015. Diverse economies, ecologies, and ethics: rethinking rural transformation in the Philippines. In G. Roelvink, K. St. Martin and J.K. Gibson-Graham (eds.). Making other worlds possible: performing diverse economies. Minneapolis, MN: University of Minnesota Press. Pp. 194-224.

Gorz, A. 1999. Reclaiming work: beyond the wage-based society. Malden: Polity Press.

Grandin, G. 2010. Fordlandia: the rise and fall of Henry Ford's forgotten Jungle City. London: Macmillan.

Hunnicutt, B. 1988. Work without end: abandoning shorter hours for the right to work. Philadelphia: Temple University Press.

Hunnicutt, B. 1992. Kellogg's six-hour day: a capitalist vision of liberation through managed work reduction. Business History Review 66: 475-522.

Illich, I. 1978. The right to useful unemployment. London: Marion Boyars.

Jacobs, J. 1985. Cities and the wealth of nations. New York: Vintage Books.

Kallis, G. 2011. In defence of degrowth. Ecological Economics 70(5): 873-880.

Kallis, G. (ed. A. Vansintjan). 2017. In defense of degrowth: opinions and manifestos. Self-published, https://indefenseofdegrowth.com

Krippner, G., M. Granovetter, F. Block, N. Biggart, T. Beamish, Y. Hsing, G. Hart, G. Arrighi, M. Mendell, J. Hall, M. Burawoy, S.Vogel and S. O'Riain. 2004. Polanyi Symposium: a conversation on embeddedness. Socioeconomic Review 2: 109-135.

Lafargue, P. 1907. The right to be lazy: and other studies. Chicago, IL: C.H. Carr.

Latouche, S. 2009. Farewell to growth. Malden: Polity Press.

Latouche, S. 2014. Imaginary, decolonization of. In D'Alisa, G., F. Demaria and G. Kallis (eds.) Degrowth: $a$ vocabulary for a new era. London: Routledge. Pp. 117-120. 
Lee, R.B. 1968. What hunters do for a living, or, how to make out on scarce resources. In Lee, R.B. and I. DeVore (eds.). Man the hunter. New Brunswick, NJ: Transaction Publishers. Pp. 31-49.

Livingston, J. 2011. Against thrift: why consumer culture is good for the economy, the environment, and your soul. New York: Basic Books.

Lockyer, J. 2017. Community, commons, and degrowth at Dancing Rabbit Ecovillage. Journal of Political Ecology 24: 519-542.

Lorek, S. and D. Fuchs. 2013. Strong sustainable consumption governance-precondition for a degrowth path? Journal of Cleaner Production 38: 36-43.

Martinez-Alier, J., I. Anguelovski, P. Bond, D. Del Bene, F. Demaria, J.F. Gerber, L. Greyl, W. Haas, H. Healy, V. Marín-Burgos, G. Ojo, M. Porto, L. Rijnhout, B. Rodríguez-Labajos, J. Spangenberg, L. Temper, R. Warlenius and I. Yánez. 2014. Between activism and science: grassroots concepts for sustainability coined by Environmental Justice Organizations. Journal of Political Ecology 21: 19-60.

Mill, J.S. 1909. Principles of political economy with some of their applications to social philosophy. $7^{\text {th }}$ Ed. London: Longmans, Green and Company.

Nørgård, J.S. 2013. Happy degrowth through more amateur economy. Journal of Cleaner Production 38: 6170.

Paulson, S. 2017. Degrowth: culture, power and change. Journal of Political Ecology 24: 425-448.

Rojek, C. 1995. Veblen, leisure and human need. Leisure Studies 14(2): 73-86.

Russell, B. 1935. In praise of idleness and other essays. London: George Allen \& Unwin.

Sahlins, M. 1968. Notes on the original affluent society. In Lee, R.B. and I. DeVore (eds.). Man the hunter. New Brunswick, NJ: Transaction Publishers. Pp. 86-89.

Schmink, M. and C.H. Wood. 1987. The political ecology of Amazonia. In Little, P., M. Horowitz and A.E. Nyerges. (eds.). Lands at risk in the third world: local-level perspectives. Boulder, CO: Westview. Pp. 38-57.

Schneider, F., G. Kallis and J. Martinez-Alier. 2010. Crisis or opportunity? Economic degrowth for social equity and ecological sustainability. Journal of Cleaner Production 18: 511-518. Researchgate

Slocum, R., and T. Gowan. 2015. Les économies alternatives dans les Corbières et la Haute Vallée de l'Aude: vers le travail non aliéné et l'approvisionnement communautaire. Journal of Political Ecology 22: 116145.

van den Bergh, Jeroen J.C.M. 2011. Environment versus growth — a criticism of "degrowth" and a plea for "agrowth." Ecological Economics 70(5): 881-890.

Van Trier, W. 1995. Everyone a king: an investigation into the meaning and significance of the debate on basic incomes with special reference to three episodes from the British inter-war experience. PhD dissertation. Leuven: Katholieke Universiteit Leuven.

Veal, A.J. 2009. The elusive leisure society. School of Leisure, Sport and Tourism Working Paper 9. Sydney: University of Technology and http://leisuresource.net/service3.aspx Veblen, T. 1934 [1899]. The theory of the leisure class. New York: Viking House.

Watson, T.J. 2009. Work and the sociological imagination the need for continuity and change in the study of continuity and change. Sociology 43(5): 861-877.

Weber, M. 2002 (1904-1905]. The protestant ethic and the spirit of capitalism. London: Penguin.

Weeks, K. 2011. The problem with work: feminism, Marxism, antiwork politics, and postwork imaginaries. Durham: Duke University Press. 